\title{
Pengaruh Aspek Pemasaran, Aspek Teknik, Dan Aspek Keuangan Studi Kelayakan Bisnis Terhadap Pendapatan Peternak Walet Di Kecamatan Lalan Kabupaten Musi Banyuasin Sumatera Selatan
}

\author{
Irsan $^{1}$, Kemas Welly Angga Permana ${ }^{2}$ \\ Fakultas Ekonomi Universitas Sjakhyakirti Palembang \\ irsan@unisti.ac.id, kemaswelly@unisti.ac.id
}

\begin{abstract}
Abstrak: Tujuan dari penelitian ini adalah untuk mengetahui bagaimana studi kelayakan bisnis usaha peternakan walet di kecamatan Lalan kabupaten Musi Banyuasin Sumatera Selatan ditinjau dari aspek keuangan, aspek pemasaran, dan aspek teknik. Sehingga dapat diketahui besaran kebutuhan dana yang diperlukan untuk sebuah investasi usaha peternakan walet. Kemudian dianalisa untuk mengetahui pengaruh ketiga aspek tersebut (aspek keuangan, aspek pemasaran, dan aspek teknik) terhadap pendapatan peternak walet baik secara parsial maupun simultan. Selain itu juga untuk mengetahui aspek kelayakan mana yang memiliki pengaruh paling dominan terhadap pendapatan peternak. Metode penelitian adalah pendekatan deskriptif kuantitatif dengan 279 sampel dari 926 peternak walet. Analisis data yang digunakan adalah analisa statistik regresi linear berganda (Uji t dan Uji F). Hasil analisis menunjukkan bahwa aspek keuangan, aspek pemasaran, dan aspek teknik secara simultan berpengaruh signifikan terhadap pendapatan peternak walet, sedangkan secara parsial, hanya aspek pemasaran dan aspek teknik yang berpengaruh secara signifikan. Dari ketiga variabel tersebut, aspek pemasaran memiliki pengaruh yang paling dominan terhadap pendapatan peternak walet.
\end{abstract}

Kata kunci: studi kelayakan bisnis; aspek keuangan; aspek pemasaran; aspek teknik; pendapatan

\begin{abstract}
The purpose of this research was to find out how the feasibility study of the swallow farm business in Lalan sub-district, Musi Banyuasin, South Sumatra in terms of financial, marketing and technical aspects. So that it can be seen the amount of funds needed for an investment in swallow farm business. Then it was analyzed to determine the effect of these three aspects (financial, marketing, and technical aspects) on the income of swallow breeders either partially or simultaneously. In addition, it was also to determine which feasibility aspect has the most dominant influence on farmer income. The research method was a quantitative descriptive approach, there are 279 samples of 926 swallow breeder businesses. The data analysis used in this study was multiple linear regression statistical analysis ( $t$ test and $F$ test). The results of the analysis show that the financial, marketing, and technical aspects simultaneously have a significant effect on swallow breeders' income, while partially, only the marketing and technical aspects have a significant effect. Of the three variables, the marketing aspect has the most dominant influence on the income of swallow breeders.
\end{abstract}

Keywords: business feasibility study; financial, marketing and technical aspects; income

\section{PENDAHULUAN}

\subsection{Latar Belakang}

Pembangunan merupakan suatu proses perubahan untuk meningkatkan taraf hidup manusia, mengejar pertumbuhan ekonomi, mengurangi kemiskinan dan tingkat pengangguran. Oleh sebab itu, penanganan masalah ini diupayakan oleh pemerintah dengan menyalurkan berbagai bantuan dan subsidi serta membuka lapangan kerja dengan meningkatkan inisiatif dan kreatifitas masyarakat di samping memperluas kesempatan investasi langsung bagi semua pihak (Saparudin, 2012). Wilayah kabupaten Musi Banyuasin khususnya pada kecamatan Lalan mempunyai potensi besar akan 


\section{Forum Bisnis Dan Kewirausahaan} Jurnal Ilmiah STIE MDP

komoditas peternakan sarang burung walet. Usaha strategis yang dapat dilakukan dalam pengembangan bidang ini salah satunya adalah dengan pembangunan dan pemberdayaan Usaha Kecil dan Menengah (UKM) budi daya peternakan sarang burung walet. Dengan luas wilayah $14.265,96 \mathrm{~km} \mathrm{\hat {A } ^ { 2 }}$ atau sekitar $15 \%$ dari luas Provinsi Sumatera Selatan terletak antara 1,3 $\hat{\mathrm{A}}^{\circ}-4 \hat{\mathrm{A}}^{\circ}$ LS dan $103 \hat{\mathrm{A}}^{\circ}-104$ 45' BT, Musi Banyuasin merupakan daerah rawa dan sungai besar serta kecil seperti Sungai Musi, Sungai Banyuasin, dan sungai Batanghari Leko sangat cocok untuk pengembangan budidaya peternakan sarang burung walet.

Sebagai komoditas konsumsi ekspor, fluktuasi harga sarang walet ini sangat tinggi yang dapat turun dan naik dengan cepat. Fluktuasi yang drastis ini tentu saja dapat mempengaruhi pendapatan peternak walet. Dengan harga jual yang relatif tinggi tersebut sementara permintaan akan pasokan sarang burung walet tetap tinggi. Berdasarkan latar belakang tersebut diatas penulis berminat untuk melakukan penelitan untuk mengetahui dan menganalisa "Pengaruh Aspek Pemasaran, Aspek Teknik, dan Aspek Keuangan Studi Kelayakan Bisnis Terhadap Pendapatan Peternak Walet di Kecamatan Lalan Kabupaten Musi Banyuasin Sumatera Selatan".

Berdasarkan latar belakang dirumuskan permasalahan:

(1) Bagaimana kelayakan bisnis peternakan walet di kecamatan Lalan kabupaten Musi Banyuasin ditinjau dari aspek keuangan, pemasaran, dan teknik?

(2) Bagaimana pengaruh secara parsial kelayakan bisnis aspek keuangan, pemasaran dan aspek teknik dari usaha peternakan walet terhadap pendapatan peternak?

(3) Bagaimana pengaruh secara simultan kelayakan bisnis aspek keuangan, aspek pemasaran, dan aspek teknik dari usaha peternakan walet terhadap pendapatan peternak?

(4) Aspek kelayakan bisnis manakah yang memiliki pengaruh paling dominan terhadap pendapatan peternak?
(5) Seberapa besar kebutuhan dana investasi usaha peternakan walet?

\subsection{Tujuan Penelitian}

Tujuan penelitian ini secara umum adalah untuk mengetahui kelayakan bisnis aspek keuangan, aspek pemasaran, dan aspek teknik peternakan walet. Sedangkan secara khusus adalah untuk mengetahui pengaruh secara parsial maupun simultan kelayakan aspek pemasaran, teknik, dan keuangan usaha peternakan walet terhadap pendapatan peternak; mengetahui aspek kelayakan manakah yang memiliki pengaruh paling dominan terhadap pendapatan peternak; dan mengetahui kebutuhan dana investasi usaha peternakan tersebut.

\section{LANDASAN TEORI}

\subsection{Pengertian Studi Kelayakan Bisnis}

Studi kelayakan bisnis adalah suatu kegiatan mempelajari dan meneliti secara sungguh-sungguh segala macam data dan informasi yang berkenaan dengan suatu kegiatan bisnis, dan selanjutnya data dan informasi itu dihitung dan dianalisis dengan suatu metode tertentu yang biasa dipakai dalam penelitian bisnis, (Abdullah, 2017). Sedangkan Purwana (2017) menyatakan studi kelayakan bisnis merupakan suatu analisis terhadap viability (diteruskan atau tidak) suatu ide. Tujuan ini memberikan pemahaman kepada pelaku usaha bahwa mengetahui lebih awal suatu ide tidak bekerja sesuai harapan. Dengan demikian dapat mencegah penggunaan uang, waktu, dan sumber daya secara sia-sia.

\subsection{Aspek - Aspek Kelayakan Bisnis}

\subsubsection{Aspek Pasar dan Pemasaran}

Menurut Purwana (2017) pasar dapat diartikan sebagai suatu mekanisme yang terjadi antara pembeli dan penjual atau tempat pertemuan antara kekuatan permintaan dan penawaran. Selanjutnya menurut Muchtar (2014) juga menjelaskan pemasaran merupakan kegiatan yang menyadari 
adanya produk dan jasa serta keuntungan yang ditawarkan. Pemasaran mencakup kegiatan mengiklankan melalui berbagai media, menghasilkan materi pendukung, seperti brosur, website, melakukan press release, dan bertugas membuat berbagai acara, seperti pameran, sponsorship, dan menawarkan sampel gratis. Selain itu analisis pasar mencakup juga gambaran mengenai strategi pemasaran yang digunakan untuk mencapai pangsa pasar yang telah ditetapkan.

\subsubsection{Aspek Teknik dan Teknologi}

Menurut Kasmir dan Jakfar (2012) Hal-hal yang perlu diperhatikan dalam aspek teknis dan Teknologi adalah masalah penentuan lokasi, luas produksi, tata letak (layout), penyusunan peralatan pabrik, dan proses produksinya termasuk pemilihan teknologi. Aspek teknik dan teknologi berkaitan dengan manajemen operasional karena manajemen operasional berkenaan dengan perencanaan proses produksi. Menurut Sunyoto (2014) manajemen operasional merupakan kegiatan mengatur/mengelola secara optimal atas sumber daya yang tersedia dalam suatu proses transformasi sehingga menjadi output yang mempunyai manfaat lebih dari sebelumnya.

\subsubsection{Aspek Keuangan}

\section{a. Pengertian Aspek Keuangan}

Menurut Kasmir dan Jakfar (2014) aspek keuangan merupakan aspek yang digunakan untuk menilai keuangan perusahaan secara keseluruhan. Aspek ini sama pentingnya dengan aspek lainnya, bahkan ada beberapa pengusaha menganggap justru aspek inilah yang paling utama untuk dianalisis karena dari aspek ini tergambar jelas hal-hal yang berkaitan dengan keuntungan perusahaan, sehingga merupakan salah satu aspek yang sangat penting untuk diteliti kelayakannya.

\section{b. Sumber dan Alat Ukur Investasi}

Menurut Kasmir dan Jakfar (2014) pembiayaan suatu usaha bersumber dari sumber dana yang diperoleh secara gabungan antar modal pribadi dan modal pinjaman. Masalah yang perlu diperhatikan berkaitan dengan perolehan modal adalah masa pengembalian modal dalam jangka waktu tertentu. Oleh karena itu, perlu dibuatkan estimasi pendapatan dan biaya sebelum usaha dijalankan yang dituangkan dalam aliran kas (cash flow) perusahaan dalam periode usaha, kemudian dinilai kelayakan investasi tersebut melalui kriteria kelayakan investasi. Alat ukur yang digunakan untuk penilaian tersebut melalui pendekatan payback period (PP), Average Rate of Return (ARR), Net Present Value (NPV), Internal Rate of Return (IRR), Profitability Index (PI), dan Break Even Point (BEP).

\subsection{Penelitian Terdahulu}

Saipullah (2018), hasil penelitian menunjukkan bahwa ditinjau dari aspek hukum usaha budidaya sarang burung walet bapak Jurni belum memenuhi syarat peraturan daerah untuk dijalankan, ditinjau dari aspek pasar dan pemasaran usaha budidaya sarang burung walet bapak Jurni layak untuk dijalankan, ditinjau dari aspek keuangan usaha budidaya sarang burung walet bapak Jurni layak untuk dijalankan, ditinjau dari aspek teknis dan teknologi usaha budidaya sarang burung walet bapak Jurni layak untuk dijalankan, dan ditinjau dari aspek lingkungan usaha budidaya sarang burung walet bapak Jurni layak untuk dijalankan.

Sudana dan Suparta (2013), hasil penelitian menunjukkan bahwa:

(1) Usaha budidaya ikan lele dumbo di Kabupaten Tabanan layak untuk diusahakan dilihat dari kelayakan aspek finansial, pemasaran dan sosial.

(2) Perubahan harga output lebih peka dibandingkan dengan perubahan harga input, berarti petani harus tanggap terhadap kondisi perubahan perkembangan harga input.

(3) Aspek pasar dan aspek sosial berada pada katagori layak dengan rata-rata skor 3,74 atau $74,78 \%$ dan 3,73 atau $74,68 \%$.

(4) Aspek pemasaran dan sosial berpengaruh signifikan terhadap pendapatan petani ikan lele. 
(5) Aspek finansial, pasar dan sosial secara simultan berpengaruh signifikan terhadap pendapatan petani ikan lele.

(6) Kelayakan aspek pemasaran memiliki pengaruh yang paling dominan terhadap pendapatan petani ikan lele dibandingkan dengan aspek finansial dan sosial.

(7)a. Pendapatan rata-rata per $\mathrm{m} 2$ kolam persiklus tertinggi diperoleh kelompok petani ikan lele dengan padat tebar benih $>200$ ekor per $\mathrm{m} 2$ kolam sebesar Rp.41.218,11, berturut-turut diikuti kelompok padat tebar benih >100-200 ekor perm2 sebesar Rp.28.069,21, dan terendah kelompok padat tebar benih $<100$ ekor per $\mathrm{m} 2$ kolam sebesar Rp.14.416,75.

(7)b. Kebutuhan modal usaha budidaya ikan lele dumbo perm2 kolam siklus I tertinggi adalah kelompok petani ikan lele dengan padat tebar benih $>200$ ekor per m2 kolam sebesar Rp. 239.337,46, berturut-turut diikuti kelompok petani dengan padat tebar benih >100 - 200 ekor perm2 kolam sebesar Rp.151.442,56, dan terendah untuk kelompok padat tebar benih < 100 ekor per m2 kolam sebesar Rp.70.134,14.

\subsection{Kerangka Konseptual Pemikiran}

Variabel-variabel yang diamati dalam penelitian ini yang terkait dengan kelayakan bisnis peternakan sarang burung walet dan pengaruhnya terhadap pendapatan peternak sarang burung walet di kecamatan Lalan kabupaten Musi Banyuasin antara lain kelayakan dari sudut aspek keuangan, pemasaran dan teknik.

Metode-metode analisis yang digunakan dalam kajian penelitian ini adalah sebagai berikut:

1. Analisis Kuantitatif, yaitu untuk menilai kriteria investasi terkait dengan analisis kelayakan aspek keuangan yang mencakup analisis undiscounted yaitu Payback Period (PP), Break Even Point (BEP). Dengan metode discounted yaitu Net Present Value (NPV), Net Benefit-Cost Ratio (Net B/C), Profitability Index (PI); dan Internal Rate of Return (IRR, dan analisis operasional usaha sarang burung walet.

2. Analisis deskriptif kualitatif, metode analisis ini menggunakan sekala jenjang yang meliputi kelayakan aspek pemasaran dan teknik.

3. Analisis Regresi Linear Berganda.

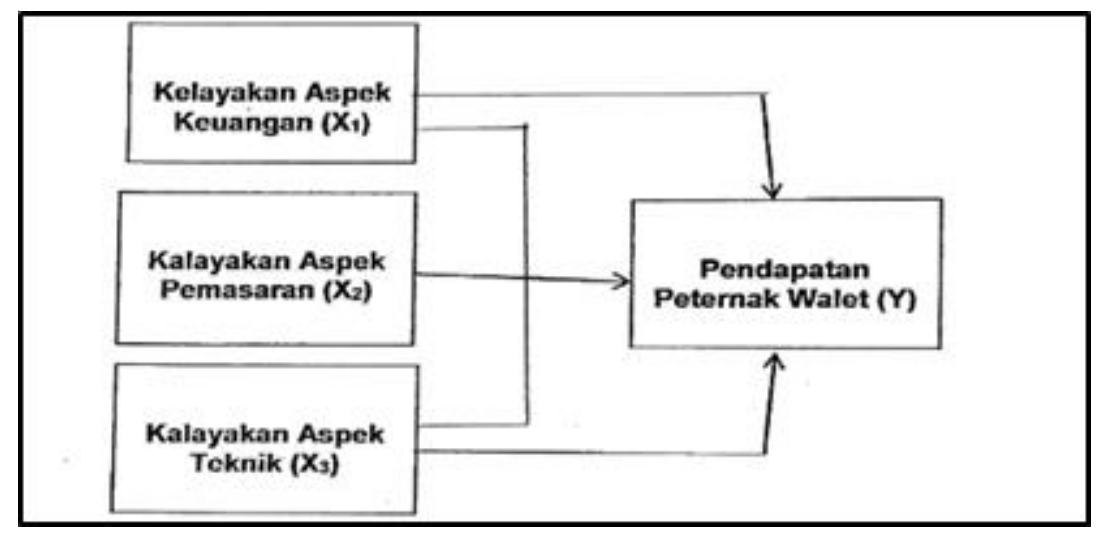

Gambar 1. Kerangka Berpikir Penelitian

\section{Hipotesis}

1. Usaha ternak sarang burung walet layak dari aspek keuangan, pemasaran dan teknik.

2. Kelayakan aspek keuangan, pemasaran, dan teknik dari usaha peternakan sarang burung walet secara parsial berpengaruh signifikan terhadap pendapatan peternak sarang burung walet.

3. Kelayakan aspek keuangan, pemasaran, dan teknik usaha peternakan sarang burung walet secara simultan berpengaruh signifikan terhadap pendapatan peternak sarang burung walet. 


\section{METODOLOGI PENELITIAN}

\subsection{Desain Penelitian}

Pendekatan yang digunakan dalam penelitian ini adalah deskriptif kuantitatif yaitu suatu proses menemukan pengetahuan yang menggunakan data berupa angka sebagai alat menemukan keterangan mengenai apa yang ingin kita ketahui (Margono, 2009). Pendekatan kuantitatif digunakan untuk meneliti populasi atau sampel tertentu. Pengumpulan data menggunakan instrumen analisis data yang bersifat statistik, dengan tujuan menguji hipotesis yang telah ditetapkan.

\subsection{Populasi dan Sampel}

Populasi merupakan keseluruhan subjek penelitian (Arikunto, 2013). Sedangkan sampel adalah bagian dari jumlah dan karakteristik yang dimiliki oleh populasi tersebut (Sugiyono 2017) Dalam penelitian ini populasi berjumlah 926 peternak dan sampel dihitung menggunakan rumus slovin dengan margin of error $5 \%$ atau 0,05 menghasilkan sampel sebanyak 279 sampel.

\subsection{Variabel Penelitian}

1. Dalam penelitian ini yang diidentifikasi sebagai variabel independen $(\mathrm{X})$ adalah:

a) kelayakan aspek keuangan (X1),

b) kelayakan aspek pemasaran (X2),

c) kelayakan aspek teknik dan teknologi (X3).

2. Dalam penelitian ini yang diidentifikasi sebagai variabel dependen (Y) adalah pendapatan peternak walet di kecamatan Lalan. Pengaruh variabel bebas $(\mathrm{X} 1, \mathrm{X} 2, \mathrm{X} 3)$ terhadap variabel terikat $(\mathrm{Y})$.

\subsection{Definisi Operasional Variabel}

1. Kelayakan aspek pemasaran, meliputi volume produksi sarang walet, kualitas produk, harga produk, distribusi penjualan produk, dan promosi produk yang diukur dengan skor.

2. Kelayakan aspek teknik dan teknologi meliputi lokasi bangunan walet, ketersediaan mesin dan peralatan, teknologi mesin dan peralatan yang digunakan, dan produksi yang optimal.

3. Kelayakan aspek keuangan meliputi:

a) Biaya investasi awal adalah biaya yang dikeluarkan sebelum usaha ternak burung walet menghasilkan meliputi: biaya pembelian tanah, konstruksi bangunan, pembelian alat-alat, yang diukur dalam rupiah.

b) Biaya operasional adalah biaya yang dikeluarkan untuk mengelola usaha yang meliputi: biaya tetap (biaya listrik, air, komunikasi, penyusutan bangunan dan peralatan) dan biaya variabel pembelian baterai, premium untuk genset, upah tenaga kerja) yang diukur dalam rupiah.

c) Penerimaan usaha merupakan perkalian antara produksi dengan harga jual diukur dalam rupiah.

d) Produksi adalah hasil yang diperoleh dari usaha sarang burung walet diukur dalam satuan kilogam.

e) Modal adalah keseluruhan aset yang digunakan dalam usaha yang meliputi modal tetap (investasi awal dan modal variabel yang diukur dalam rupiah).

4. Pendapatan peternak adalah total pendapatan bersih yang diperoleh dari seluruh aktivitas usaha ternak walet yang merupakan selisih antara total penerimaan dengan total biaya yang dikeluarkan diukur dalam rupiah.

\subsection{Teknik Analisis Data}

1. Analisis operasional, yaitu analisis usaha ternak walet meliputi produksi, penerimaan, penjualan, biaya produksi, pendapatan dan kebutuhan modal.

2. Analisis Kriteria Investasi

A. Kriteria investasi dengan undisconted dinilai menggunakan metode:

(a) Payback Period (PP); dan

(b) Break Even Point (BEP).

B. Kriteria investasi dengan discounted dinilai menggunakan metode:

(a) Net Present Value (NPV);

(b) Net Benefit-Cost Ratio (Net B/C); 
(c) Profitability Index (PI); dan

(d) Internal Rate of Return (IRR).

3. Analisis deskriptif kualitatif

Data persepsi peternak walet diukur dengan sekala jenjang dengan skor tertinggi 5 dan terendah 1. Uji validitas menggunakan teknik korelasi Pearson Product Moment (Sugiyono, 2002). Uji reliabilitas menggunakan uji koefisien Alpha Cronbach dalam (Anwar, 2001). Sebelum data skor aspek kelayakan pemasaran dan teknik dimasukkan dalam perhitungan model regresi, terlebih dahulu data dimaksud ditransformasi menjadi data interval dengan menggunakan method of successive interval (Sugiyono, 2008)

4. Analisis inferensial

Dalam penelitian ini uji statistik yang digunakan untuk mengetahui pengaruh variabel bebas yaitu kelayakan aspek keuangan, pemasaran dan tekniik terhadap variabel terikat yakni pendapatan peternak sarang burung walet di Kecamatan Lalan dengan metode analisis regresi linear berganda adalah sebagai berikut (Natawirawan, 2002):

$\mathrm{Y}=\mathrm{a}+\mathrm{b} 1 \mathrm{X} 1+\mathrm{b} 2 \mathrm{X} 2+\mathrm{b} 3 \mathrm{X} 3+\mathrm{ei}$

Sebelum dilakukan pengujian dengan analisis regresi, data penelitian diuji dengan uji asumsi klasik. Kemudian untuk pengujian hipotesis dilakukan uji $\mathrm{F}$ dan uji t. Untuk menentukan variabel yang paling dominan menggunakan nilai standrdized coefficient beta.

\section{HASIL DAN PEMBAHASAN}

\subsection{Hasil Penelitian}

\subsubsection{Profil Responden}

Untuk menganalisis profil responden, digunakan tabel frekuensi yang terdiri dari jenis kelamin, usia dan pendidikan seperti pada tabel berikut:

Tabel 1. Jenis Kelamin, Usia, Pendidikan Responden

\begin{tabular}{lccc}
\hline Jenis Kelamin & Frekuensi & Persentase (\%) \\
\hline Laki-laki & & 276 & 98.92 \\
Perempuan & & 279 & 1.08 \\
\hline & Total & Frekuensi & 100.00 \\
\hline Usia & & 26 & Persentase (\%) \\
\hline $26-35$ & & 142 & 9.32 \\
$36-45$ & 111 & 50.90 \\
46-ke atas & & 279 & 39.79 \\
\hline & Total & Frekuensi & 100.00 \\
\hline Pendidikan & & 186 & Persentase (\%) \\
\hline SD/SLTP & & 87 & 66.66 \\
SLTA & 6 & 0 & 31.18 \\
S1 & Total & 279 & 2.16 \\
S2 & & & 100.00 \\
\hline
\end{tabular}

Sumber: Data dioleh

Profil responden berdasarkan jenis kelamin dapat dilihat pada tabel 1. bahwa para peternak berjenis kelamin laki-laki sebanyak 276 orang atau sebesar 98,92\%, sedangkan peternak berjenis kelamin perempuan berjumlah 3 orang atau $1,08 \%$. Hal ini terlihat bahwa jumlah peternak laki-laki sangat dominan dibandingkan dengan peternak perempuan.

Jika dilihat berdasarkan usia, merujuk pada teori perkembangan psikososial Erikson, dikutip dari 


\section{Forum Bisnis Dan Kewirausahaan}

Jurnal Ilmiah STIE MDP

Whalley \& Wong's (1999), tahap perkembangan manusia menurut umur dibagi dalam delapan tahapan. Tiga diantaranya berkaitan dengan penelitian ini, yaitu kelompok dewasa awal (26-35), dewasa pertengahan (36-45) dan dewasa (diatas 45). Pada tabel di atas terlihat bahwa responden berusia 26-35 tahun sebanyak 26 orang atau $9.32 \%$. Sebanyak 142 orang berusia antara 36-45 tahun (50.90\%) dan usia 46 tahun ke atas sebanyak 111 orang atau $39.79 \%$. Hal ini memperlihatkan bahwa responden peternak walet di kecamatan Lalan didominasi peternak usia produktif.

Pada profil responden berdasarkan pendidikan terlihat bahwa sebagian besar responden berpendidikan SD/SLTP yaitu sebanyak 186 orang atau $66.66 \%$ sedangkan yang berpendidikan SLTA sebesar $31.18 \%$ atau 87 orang dan yang berpendidikan S1 sebanyak 6 orang atau $2.16 \%$. Dengan demikian dapat disimpulkan bahwa peternak walet di kecamatan Lalan didominasi oleh peternak yang berpendidikan sederajat SD/SLTP.

\subsubsection{Analisis Deskriptif Variabel Penelitian}

\subsubsection{Analisis Aspek Keuangan}

Berdasarkan hasil survey, observasi dan melalui catatan-catatan dan dokumentasi yang penulis miliki, untuk membangun sebuah konstruksi rumah burung walet (RBW) dengan bangunan permanen ukuran 4 meter x 12 meter x 3 lantai di kecamatan Lalan kabupaten Musi Banyuasin Sumatera Selatan dibutuhkan dana investasi awal dan amortisasi pada tabel 2 sebagai berikut:

Tabel 2. Dana Investasi dan Amortisasi RBW Ukuran 4 x 12 x 3 Lantai

\begin{tabular}{|c|c|c|c|c|c|}
\hline No. & INVESTASI & JUMLAH & NILAI SISA & UMUR EKONOMIS & PENUSUTAN/BLN \\
\hline 1 & Pembangunan Rumah Burung walet & 165.078 .000 & 10.317 .375 & 15 Tahun & 10.317 .375 \\
\hline 2 & BIaya IzIn IMB & 6.480 .000 & 6.480 .000 & & \\
\hline 3 & Blaya Perlengakan RBW & 11.881 .100 & 1.188 .110 & 15 Tahun & 712.866 \\
\hline 4 & Peralatan Panen & 3.000 .000 & 300.000 & 15 Tahun & 180.000 \\
\hline & TOTAL INVESTASI & 186.439 .100 & 18.285 .485 & & 11.210 .241 \\
\hline
\end{tabular}

Sumber: Dokumentasi Penulis, 2019, diolah

Selama kurun waktu tahun pertama sampai dengan tahun ke lima belas (umur proyek) terdapat biaya operasional yang terdiri dari biaya pemeliharaan berupa penyemprotan hama jamur dan bakteri di dalam RBW yang dilakukan secara rutin setiap 3 bulan sekali, biaya tenaga kerja, biaya listrik dan biaya air. Biaya operasional tersebut diprediksikan selama 15 tahun seperti dalam tabel 3 sebagai berikut:

Tabel 3. Dana Operasional Tahun ke1 sampai dengan Tahun ke 15

\begin{tabular}{|c|c|c|c|c|c|}
\hline Tahun & Biaya & Upah Tenaga & Biaya & Biaya Air & Total \\
\hline & Permeliharaan & Kerja & Listrik & & B. Operasional \\
\hline 1 & 600.000 & 1.200 .000 & 1.200.000 & 600.000 & 3.600 .000 \\
\hline 2 & 660.000 & 9.720 .000 & 1.320 .000 & 660.000 & 12.360 .000 \\
\hline 3 & 726.000 & 24.300 .000 & 1.452 .000 & 726.000 & 27.204 .000 \\
\hline 4 & 798.600 & 24.300 .000 & 1.597 .200 & 798.600 & 27.494 .400 \\
\hline 5 & 979.460 & 48.600 .000 & 1. 756.920 & 978.460 & 52.113 .840 \\
\hline 6 & 966.306 & 49.600 .000 & 1.932 .612 & 966.306 & 52.465 .224 \\
\hline 7 & 1.062 .937 & 48.600 .000 & 2.125 .973 & 1.062 .937 & 52.851 .746 \\
\hline $\mathbf{8}$ & 1.169 .230 & 48.600 .000 & 2.339 .461 & 1. 169.230 & 53.276 .921 \\
\hline 9 & 1.296 .153 & 48.600 .000 & 2.572 .307 & 1.296 .153 & 53.744 .613 \\
\hline 10 & 1.414 .769 & 48.600 .000 & 2.829 .537 & 1.414 .769 & 54.259 .074 \\
\hline 11 & 1.556 .245 & 48.600 .000 & 3.112 .491 & 1.556 .245 & 54.824 .982 \\
\hline 12 & 1.711 .870 & 48.600 .000 & 3.423 .740 & 1.711 .870 & 55.447 .480 \\
\hline 13 & 1.893 .057 & 48.600 .000 & 3. 766.114 & 1.893 .057 & 56.132 .228 \\
\hline 14 & 2.071 .363 & 48.600 .000 & 4.142 .725 & 2.071 .363 & 56.885 .451 \\
\hline \multirow[t]{2}{*}{15} & 2.279 .499 & 48.600 .000 & 4.556 .998 & 2.278 .499 & 57.713 .996 \\
\hline & 19.063 .489 & 594.120 .000 & 38.126 .978 & 19.063 .489 & 670.373 .956 \\
\hline
\end{tabular}

Sumber: dokumentasi penulis, 2019, diolah 


\section{Forum Bisnis Dan Kewirausahaan Jurnal Ilmiah STIE MDP}

Kemudian untuk menentukan net benefit diperliukan proyeksi produksi, estimasi harga jual sarang burung walet, dan perhitungan pajak sarang burung walet dapat dilihat dalam tabel 4. berikut:

Tabel 4. Proyeksi Net Benefit dan Cost

\begin{tabular}{|c|c|c|c|c|c|c|c|}
\hline Tahun & Produksi & Harga & Benefit & Tax & Amortisasi & Cost & Net Benefit \\
\hline 0 & - & & & & & 186.439 .100 & 186.439 .100 \\
\hline 1 & - & & & & 11.210 .241 & 3.600 .000 & $\begin{array}{r}14.810 .241 \\
201.249 .341\end{array}$ \\
\hline 2 & 2,4 & 13.500 .000 & 32.400 .000 & 3.240 .000 & 11.210 .241 & 12.360 .000 & 5.589 .759 \\
\hline 3 & 6,0 & 13.500 .000 & 81.000 .000 & 8.100 .000 & 11.210 .241 & 27.204 .000 & 34.485 .759 \\
\hline 4 & 6,0 & 13.500 .000 & 81.000 .000 & 8.100 .000 & 11.210 .241 & 27.494 .400 & 34.195 .359 \\
\hline 5 & 12,0 & 13.500 .000 & 162.000 .000 & 16.200.000 & 11.210 .241 & 52.113 .840 & 82.475 .919 \\
\hline 6 & 12,0 & 13.500 .000 & 162.000 .000 & 16.200 .000 & 11.210 .241 & 52.465 .224 & 82.124 .535 \\
\hline 7 & 12,0 & 13.500 .000 & 162.000 .000 & 16.200.000 & 11.210 .241 & 52.851 .746 & 81.738 .013 \\
\hline 8 & 12,0 & 13.500 .000 & 162.000 .000 & 16.200 .000 & 11.210 .241 & 53.276 .921 & 81.312 .838 \\
\hline 9 & 12,0 & 13.500 .000 & 162.000 .000 & 16.200 .000 & 11.210 .241 & 53.744 .613 & 80.845 .146 \\
\hline 10 & 12,0 & 13.500 .000 & 162.000 .000 & 16.200 .000 & 11.210 .241 & 54.259 .074 & 80.330 .685 \\
\hline 11 & 12,0 & 13.500 .000 & 162.000 .000 & 16.200 .000 & 11.210 .241 & 54.824 .982 & 79.764 .777 \\
\hline 12 & 12,0 & 13.500 .000 & 162.000 .000 & 16.200 .000 & 11.210 .241 & 55.447 .480 & 79.142 .279 \\
\hline 13 & 12,0 & 13.500 .000 & 162.000 .000 & 16.200 .000 & 11.210 .241 & 56.132 .228 & 78.457 .531 \\
\hline 14 & 12,0 & 13.500 .000 & 162.000 .000 & 16.200 .000 & 11.210 .241 & 56.885 .451 & 77.704 .308 \\
\hline \multirow[t]{2}{*}{15} & 12,0 & 13.500 .000 & 162.000 .000 & 16.200 .000 & 11.210 .241 & 57.713 .996 & 76.875 .763 \\
\hline & & & 1.976 .400 .000 & 197.640 .000 & 168.153 .615 & 856.813 .056 & 955.042 .670 \\
\hline
\end{tabular}

Sumber: Dokumentasi Penulis, 2019, diolah

\section{Perhitungan Kriteria Investasi}

\section{(1) Payback Period (PP)}

Merupakan uji kelayakan investasi dengan cara mengukur jangka waktu pengembalian investasi. Aliran kas (cash flow) adalah dasar perhitungan yang digunakan sehingga metode perhitungan adalah discounted, seperti tampak pada tabel berikut ini:

Tabel 5. Cash Flow RBW Uk. 4 x 12 x 3Lt

\begin{tabular}{|c|c|c|c|c|c|c|c|c|}
\hline TAHUN & & NET BEN EFIT & PENYUSUTAN & & KAS BERSIH & DF $12 \%$ & PV & KAS BERSIH \\
\hline 1 & - & 14.810 .241 & 11.210 .241 & - & 3.600 .000 & $0, \boldsymbol{\Xi \unlhd \Xi}$ & - & 3.214 .800 \\
\hline 2 & & 5.589.759 & 11.210 .241 & & 16.800 .000 & 0,797 & & 13.389 .600 \\
\hline 3 & & 34.485 .759 & 11.210 .241 & & 45.696 .000 & 0,712 & & 32.535 .552 \\
\hline 4 & & 34.195 .359 & 11.210 .241 & & 45.405 .600 & 0,636 & & 28.877 .962 \\
\hline 5 & & 82.475 .919 & 11.210 .241 & & $93.6 \Xi 6.160$ & 0,567 & & 53.120 .053 \\
\hline 6 & & 82.124 .535 & 11.210 .241 & & 93.334 .776 & 0,507 & & 47.320 .731 \\
\hline 7 & & 81.73 8.013 & 11.210 .241 & & 92.948 .254 & 0,452 & & 42.012 .611 \\
\hline 8 & & \&1.312.838 & 11.210 .241 & & 92.523 .079 & 0,404 & & 37.379 .324 \\
\hline 9 & & 80.845 .146 & 11.210 .241 & & 92.055 .387 & 0,361 & & 33.231 .995 \\
\hline 10 & & 80.330.6อ5 & 11.210 .241 & & 91.540 .926 & 0,322 & & 29.476 .178 \\
\hline 11 & & 79.764 .777 & 11.210 .241 & & 90.975 .018 & 0,287 & & 26.109 .830 \\
\hline 12 & & 79.142 .279 & 11.210 .241 & & 90.352 .520 & 0,257 & & 23.220 .598 \\
\hline 13 & & 78.457 .531 & 11.210 .241 & & 89. 667.772 & 0,229 & & 20.533 .920 \\
\hline 14 & & 77.704 .308 & 11.210 .241 & & 89.914 .549 & 0,205 & & 18.227 .483 \\
\hline 15 & & 76.875 .763 & 11.210 .241 & & 88.086 .004 & 0,183 & & 16.119 .739 \\
\hline
\end{tabular}

Sumber: dokumentasi penulis, 2019, diolah

Investasi RBW $\quad \mathrm{Rp} 186.439 .100$

Kas bersih tahun ke 1 Rp - 3.600 .000

Rp 190.039.100

Kas bersih tahun ke $2 \quad \mathrm{Rp} \quad 16.800 .000$ Rp 173.239.100
Kas bersih tahun ke $3 \underline{\mathrm{Rp} \quad 45.696 .000}$

$\mathrm{Rp} 127.543 .100$

Kas bersih tahun ke $4 \underline{\mathrm{Rp} \quad 45.405 .600}$

Rp 82.137.500

Kas bersih tahun ke 5 adalah sebesar Rp 82.137.500/ 
93.686.160 $\times 12$ bulan $=10,52$ bulan atau dibulatkan menjadi 11 bulan.

Dari perhitungan di atas diperoleh jangka waktu pengembalian investasi RBW ukuran 4 X 12 X 3 Lantai tersebut adalah selama 4 tahun 11 bulan.

\section{(2) Break Event Point (BEP)}

BEP adalah keadaan usaha yang telah mencapai suatu titik tidak untung dan juga tidak rugi atau pada titik impas.

$$
\begin{aligned}
\text { BEP } & =\frac{F C}{P-V C} \\
\text { BEP } & =\frac{19.063 .489+38.126 .978+19063.489+168.153615}{13.500 .00-\frac{9.720 .000+3.240 .000}{2,4 k g}} \\
& =30,17377421 \mathrm{~kg} \text { atau } 30,17 \mathrm{~kg} \\
\text { BEP } & =\frac{244.407 .571}{1-\left(\frac{5.400 .000}{13.500 .000}\right)}=\frac{244.407 .571}{0,6} \\
& =\text { Rp } 407.345 .952,-
\end{aligned}
$$

\section{(3) Net Present Value dari Arus Benefit dan Arus Cost (NPV)}

NPV menunjukkan keuntungan yang akan diperoleh selama umur investasi dan merupakan selisih atau varian antara nilai yang sekarang dari manfaat dengan biaya pada tingkat diskonto tertentu.

\section{NetB /C -}

$$
\sum_{t=0}^{n} \frac{(B t-C t)}{(1+i)}(+)
$$

$$
\sum_{t=0}^{n} \frac{(B t-C t)}{(1+i)}(-)
$$

$\mathrm{NPV}=$ Total PV Kas Bersih $-\mathrm{PV}$ Investasi

$=\operatorname{Rp} 418.340 .774-\mathrm{Rp} 186.439 .100$

$=\mathrm{Rp} 231.901 .674$ (NPV positif)

\section{(4) Profitability Index (PI)}

Profitability Index (PI) adalah metode yang menghitung perbandingan antara nilai sekarang penerimaan kas bersih di masa yang akan datang (proceeds) dengan nilai sekarang investasi (outlays).

$$
\begin{aligned}
& \mathrm{PI}=\frac{\text { Total PV Kas Bersih }}{\text { PV Investasi }} \\
& \mathrm{PI}=\frac{418 \cdot 340.774}{186.439 .100}=2,2 \text { kali }
\end{aligned}
$$

\section{(5) Net Benefit/Cost Ratio (Net B/C)}

Net B/C merupakan metode yang membandingkan jumlah NPV positif dengan NPV negatif. Hasil perhitungannya dapat menggambarkan benefit yang akan diperoleh berapa kali lipat dari cost yang dikeluarkan. Dari data-data pada tabel 3 dapat dihitung Net B/C sebagai berikut:

Net $B / C=\frac{995.042 .670}{201 \cdot 249.341}=4,75$

\section{(6) Internal Rate of Return (IRR)}

Internal Rate of Return (IRR) adalah metode untuk menghitung tingkat bunga yang dapat menyamakan antara present value dari semua aliran kas masuk dengan aliran kas keluar dari suatu investasi seperti pada tabel 6 . berikut ini: 
Tabel 6. Nilai IRR Usaha RBW

\begin{tabular}{|c|c|c|c|c|c|}
\hline TAHUN & KAS BERSIH & DF $26 \%$ & PV KAS BERSIH & DF $27 \%$ & PV KAS BERSIH \\
\hline 1 & 3.600 .000 & $0.800-$ & 2.880.000 & $0.787-$ & 2.833 .200 \\
\hline 2 & 16.800 .000 & 0.840 & 10.752 .000 & 0.620 & 10.416 .000 \\
\hline 3 & 45.696 .000 & 0.512 & 23.396 .352 & 0.488 & 22.299 .648 \\
\hline 4 & 45.405 .600 & 0.410 & 18.598 .134 & 0.384 & 17.435 .750 \\
\hline 5 & 93.686 .160 & 0.328 & 30. 700.955 & 0.303 & 28.386 .906 \\
\hline 6 & 93.334 .776 & 0.282 & 24.463 .045 & 0.238 & 22.213 .677 \\
\hline 7 & 92.948 .254 & 0.210 & 19.491 .249 & 0.188 & 17.474 .272 \\
\hline 8 & 92.523 .079 & 0.188 & 15.525 .373 & 0.148 & 13.693 .416 \\
\hline 9 & 92.055 .387 & 0.134 & 12.353 .833 & 0.118 & 10.678 .425 \\
\hline 10 & 91.540 .926 & 0.107 & 9.831 .495 & 0.092 & 8.421 .765 \\
\hline 11 & 90.975 .018 & $0.08 B$ & 7.814 .754 & 0.072 & 6.550 .201 \\
\hline 12 & 90.352 .520 & O. OBS & 6.207.218 & 0.057 & 5.150 .094 \\
\hline 13 & 89.667.7フ2 & 0.055 & 4.931 .727 & 0.045 & 4.035 .050 \\
\hline 14 & 88.914 .549 & 0.044 & 3.912 .240 & 0.035 & 3.112 .009 \\
\hline \multirow[t]{2}{*}{15} & 83.086 .004 & 0.035 & 3.100 .627 & 0.028 & 2.466 .408 \\
\hline & & & 188.199 .002 & & 169.500 .421 \\
\hline
\end{tabular}

Sumber: dokumentasi penulis, 2019, diolah

NPV Positif

$\mathrm{NPV}=188.199 .002-186.439 .100=1.759 .902$

NPV Negatif

$\mathrm{NPV}=169.500 .421-186.439 .100=-16.938 .679$

$\mathrm{IRR}=i 1+\frac{N P V_{1}}{N P V_{1}-N P V_{2}}\left(i_{2}-i_{1}\right)$

$I R R=0.26+\left[\frac{1.759 .902}{1.759 .902+16.938 .679}(0,27-0,26)\right]$ $=0,26$ atau $26 \%$

\subsubsection{Analisis Aspek Pemasaran}

Usaha peternakan walet ini layak dari segi aspek pemasaran, hal ini dapat dilihat dari skor ratarata hasil wawanca dalam kuisioner dengan responden sebesar 3,88 atau 77,71 termasuk kategori layak.

\subsubsection{Analisis aspek Teknik}

Usaha peternakan walet ini juga layak dari aspek teknk hal ini dibuktikan dari skor rata-rata hasil wawanca dalam kuisioner dengan responden sebesar 3,73 atau 74,67 termasuk kategori layak.

\subsubsection{Analisis Statistik}

\subsubsection{Hasil Uji Validitas}

Uji Validitas dilakukan untuk mengukur sejauhmana alat pengukur dapat mengukur apa yang hendak diukur, hasil analisis menunjukkan bahwa item-item pernyataan pada variabel-variabel valid pada taraf nyata $5 \%$, karena nilai koefisien korelasi atau $r$ hitung $>r$ tabel (uji 2 sisi dengan signifikansi 0.05) dan jumlah data $(\mathrm{n}-2)=279-2=277$ adalah $\mathrm{r}$ tabel $=0.117$. Hal ini menunjukkan bahwa item-item tersebut dapat dijadikan sebagai indikator terhadap variabel kuisioner ini.

\subsubsection{Hasil Uji Reliabilitas}

Uji reliabilitas dipergunakan untuk mendapatkan data sesuai dengan tujuan pengukuran. Untuk itu dilakukan uji reliabilitas dalam penelitian ini menggunakan Alpha Cronbach's diukur berdasarkan skala Alpha Cronbach's dengan angka 0 sampai 1. Menurut Sujiono (2007), reliabilitas suatu konstruk variabel dikatakan baik jika memiliki nilai Alpha Cronbach's lebih dari 0.6. Berdasarkan hasil analisis, nilai alpha sebesar 0.723 lebih dari 0.117 maka dapat disimpulkan bahwa butir-butir instrumen penelitian reliabel.

\subsubsection{Analisis Pengaruh Variabel Independen Terhadap Variabel Dependen}

Analisis pengaruh variabel aspek keuangan (X1), aspek pemasaran (X2), aspek teknik (X3), 
terhadap pendapatan peternak walet (Y), menggunakan regresi linear berganda dengan bantuan SPSS versi 23.0, berikut adalah rangkuman hasil perhitungan tampak dalam tabel di bawah ini.

Tabel 7. Hasil Analisis Aspek Keuangan (X1), Pemasaran (X2), Teknik (X3) Terhadap Pendapatan Peternak Walet (Y) di Kecamatan Lalan Kabupaten Musi Banyuasin

\begin{tabular}{|c|c|c|c|c|c|c|}
\hline Variabel & $\mathbf{B}$ & & & B & $\mathbf{t}$ & Sig \\
\hline Constanta & Bo & $=$ & -13.473 .147 .321 & & -6.632 & .000 \\
\hline Aspek Keuangan (X1) & $\mathrm{B}_{1}$ & $=$ & -.014 & $\beta_{1}=-0.037$ & -1.495 & .136 \\
\hline Aspek Pemasaran $(X 2)$ & $B 2$ & $=$ & 803.284 .191 & $\beta_{2} 2=-0.490$ & 9.342 & .000 \\
\hline Aspek Teknik (X3) & $\mathrm{B} 3$ & $=$ & 318.373 .050 & $\beta^{3}=-0.178$ & 3.398 & .001 \\
\hline $\mathrm{R}$ & & $=$ & 0.585 & & FnItung = & 47.811 \\
\hline R Square & & $=$ & 0.343 & & Sig $F=$ & 0.000 \\
\hline R Adjusted Square & & $=$ & 0.336 & & & \\
\hline
\end{tabular}

Sumber: Data diolah

Dalam pengujian terhadap hipotesis dilakukan dengan analisis statistik. Untuk membuat suatu kesimpulan yang dapat dijadikan ukuran terhadap parameter dalam populasi perlu dilakukan pengujian secara statistik.

\subsubsection{Hasil Analisis Regresi Linear Berganda}

Dari hasil pengolahan data analisis pada tabel 7. permodelan regresi yang didapat adalah sebagai berikut:

$\mathrm{Y}=\alpha+\beta 1 \mathrm{X} 1+\beta 2 \mathrm{X} 2+\beta 3 \mathrm{X} 3+\varepsilon \mathrm{c}$

$Y=-13.473 .147 .32-0.014+803.284 .19+$

318.373 .05

Dimana:

$\mathrm{Y} \quad=$ Pendapatan $(\%)$

$\alpha \quad=$ konstanta

$\beta 1, \beta 2, \beta 3=$ koefisien regresi

$\mathrm{X} 1=$ Aspek Keuangan

$\mathrm{X} 2=$ Aspek Pemasaran

$\mathrm{X} 3=$ Aspek Teknik

Dari hasil model regresi linear berganda yang terbentuk menunjukkan bahwa variabel aspek keuangan (X1) berpengaruh negatif terhadap pendapatan peternak walet $(\mathrm{Y})$ dan variabel aspek pemasaran (X2) dan aspek teknik (X3) berpengaruh positif terhadap pendapatan peternak walet (Y).

Berdasarkan tabel 7. di atas, nilai koefisien dan signifikansi masing-masing variabel dapat diuraikan dalam analisis regresi linier secara parsial (Uji-t).

\subsubsection{Hasil Analisis Regresi Linear secara Parsial (Uji-t)}

Uji-t digunakan untuk mengetahui apakah model regresi variabel bebas secara parsial berpengaruh signifikan terhadap variabel terikat seperti pada tabel 7. bahwa diperoleh nilai $p$-value yang bernilai < dari 0.05 , pada tingkat kepercayaan sebesar $95 \%$ dapat dijelaskan bahwa pengaruh masing-masing variabel bebas terhadap variabel terikat adalah sebagai berikut:

\section{a. Pengaruh Aspek Keuangan (X1) Terhadap Pendapatan Peternak Walet (Y)}

Berdasarkan hasil pengujian tingkat signifikan hitung sebesar $0.136>$ dari 0.05 pada tingkat kepercayaan 95\%, artinya tidak berpengaruh signifikan antara aspek keuangan terhadap pendapatan peternak.

\section{b. Pengaruh Aspek Pemasaran (X2) Terhadap Pendapatan Peternak Walet (Y)}

Berdasarkan hasil pengujian tingkat signifikan hitung sebesar $0.000<$ dari 0.05 pada tingkat kepercayaan $95 \%$, artinya ada pengaruh signifikan antara aspek pemasaran terhadap pendapatan peternak.

\section{c. Pengaruh Aspek Teknik (X3) Terhadap Pendapatan Peternak Walet (Y)}

Berdasarkan hasil pengujian tingkat signifikan hitung sebesar $0.001<$ dari 0.05 pada tingkat kepercayaan $95 \%$, artinya ada pengaruh signifikan antara aspek teknik terhadap pendapatan peternak. 


\subsubsection{Koefisien Korelasi Ganda}

Koefisien korelasi ganda digunakan untuk mengetahui hubungan antara variabel independen (X1, X2, X3) terhadap variabel dependen (Y) secara serentak. Berdasarkan keofisien korelasi ganda (r) diketahui bahwa koefisien korelasi ganda antara aspek keuangan (X1), aspek pemasaran (X2) dan aspek teknik (X3) dengan pendapatan peternak walet (Y) sebesar 0.585. Hasil ini menunjukkan bahwa secara bersama-sama atau simultan ketiga variabel tersebut memiliki hubungan yang kuat dengan variabel pendapatan adalah sebesar $58.5 \%$.

\subsubsection{Koefisien Determinan}

Analisis determinasi digunakan untuk mengetahui persentase sumbangan pengaruh variabel independen secara serentak terhadap variabel dependen (Y). Berdasarkan tabel 7, analisis determinan Nilai $\mathrm{r}$-Square $\left(\mathrm{r}^{2}\right)$ sebesar 0.343 menunjukkan bahwa persentase hubungan pengaruh variabel independen (aspek keuangan, aspek pemasaran dan aspek teknik) terhadap variabel dependen (pendapatan) sebesar $34.3 \%$ atau dengan kata lain bahwa variabel pendapatan (Y) dapat dijelaskan oleh variabel aspek keuangan (X1) aspek pemasaran (X2), dan aspek teknik (X3) sebesar $34.3 \%$.

\subsubsection{Hasil Analisis Regresi Linear secara Simultan (Uji-F)}

Uji-F merupakan uji model yang dilakukan untuk menguji keberartian persamaan regresi linear berganda dan keberartian pengaruh variabel independen yaitu aspek keuangan (X1) aspek pemasaran (X2), dan aspek teknik (X3) secara bersama-sama atau simultan berpengaruh terhadap variabel dependen yaitu pendapatan (Y).

Berdasarkan tabel 7 , tingkat signifikansi sebesar 0.05 , dengan tingkat signifikansi hitung sebesar $0.000<0.05$, artinya ada pengaruh signifikan pada variabel independen; aspek keuangan (X1) aspek pemasaran (X2), dan aspek teknik (X3) terhadap pendapatan $(\mathrm{Y})$.

\subsection{Hasil Pengujian Hipotesis}

H1: Usaha ternak sarang burung walet layak dari aspek keuangan, pemasaran dan teknik adalah terbukti.

\section{Pembuktian hipotesis:}

\section{Kelayakan Aspek Keuangan}

Usaha peternakan walet di kecamatan Lalan dapat dikatakan layak dari segi aspek finansial Payback period (PP) selama 4 tahun 11 bulan < dari umur proyek. BEP tercapai pada produksi sebanyak $30,17 \mathrm{~kg}$ atau penjualan pada nilai $\mathrm{Rp}$ 407.345.952 Nilai Net Present Value (NPV) positif pada tingkat suku bunga $12 \%$ sebesar Rp 231.901.674 >0,00, Profitability Index (PI) sebesar 2,2 yang berarti > 1. Net Benefit/Cost Ratio (Net B/ C) 4,75 kali, dan Internal Rate of Return (IRR) $26 \%$ $>$ dari suku bunga pinjaman $12 \%$. Hasil ini memberibukti bahwa ditinjau dari aspek keuangan layak untuk dilaksanakan.

\section{Kelayakan Aspek Pemasaran}

Usaha peternakan walet ini layak dari segi aspek pemasaran, hal ini dapat dilihat dari skor ratarata hasil wawanca dalam kuisioner dengan responden sebesar 3,88 atau 77,71 termasuk kategori layak.

\section{Kelayakan Aspek Teknik}

Usaha peternakan walet ini juga layak dari aspek teknk hal ini dibuktikan dari skor ratarata hasil wawanca dalam kuisioner dengan responden sebesar 3,73 atau 74,67 termasuk kategori layak.

H2: Kelayakan aspek keuangan secara parsial berpengaruh signifikan terhadap pendapatan peternak sarang burung walet tidak terbukti sedangkan kelayakan aspek pemasaran dan teknik secara parsial berpengaruh signifikan terhadap pendapatan peternak sarang burung walet adalah terbukti. 


\section{Pembuktian hipotesis:}

Berdasarkan hasil analisa Uji-t diperoleh nilai $p$-value yang bernilai < dari 0.05 , pada tingkat kepercayaan sebesar $95 \%$ dapat dijelaskan bahwa pengaruh masing-masing variabel bebas terhadap variabel terikat sebagai berikut:

\section{Pengaruh Aspek Keuangan (X1) Terhadap Pendapatan Peternak Walet (Y)}

Berdasarkan hasil pengujian tingkat signifikan hitung sebesar $0.136>$ dari 0.05 pada tingkat kepercayaan 95\%, artinya tidak berpengaruh signifikan antara aspek keuangan terhadap pendapatan peternak.

\section{Pengaruh Aspek Pemasaran (X2) Terhadap Pendapatan Peternak Walet (Y)}

Berdasarkan hasil pengujian tingkat signifikan hitung sebesar $0.000<$ dari 0.05 pada tingkat kepercayaan $95 \%$, artinya ada pengaruh signifikan antara aspek pemasaran terhadap pendapatan peternak.

\section{Pengaruh Aspek Teknik (X3) Terhadap Pendapatan Peternak Walet (Y)}

Berdasarkan hasil pengujian tingkat signifikan hitung sebesar $0.001<$ dari 0.05 pada tingkat kepercayaan $95 \%$, artinya ada pengaruh signifikan antara aspek teknik terhadap pendapatan peternak.

H3: Kelayakan aspek keuangan, pemasaran, dan teknik usaha peternakan sarang burung walet secara simultan berpengaruh signifikan terhadap pendapatan peternak sarang burung walet adalah terbukti.

\section{Pembuktian hipotesis:}

Berdasarkan hasil analisis Uji-F dari perhitungan regresi linear berganda pada tingkat kepercayaan $95 \%$ atau tingkat signifikansi 0.005 diperoleh nilai probabilitas variabel aspek keuangan (X1), variabel aspek pemasaran X2), dan variabel aspek teknik (X3) secara simultan (sig. F) sebesar 0.000 . Karena nilai probabilitas variabel (X1), (X2), dan (X3) lebih kecil dengan 0.05, maka dapat disimpulkan bahwa variabel aspek keuangan (X1), variabel aspek pemasaran (X2), dan variabel aspek teknik (X3) secara simultan berpengaruh signifikan terhadap variabel pendapatan (Y) pada peternak sarang burung walet. Besarnya pengaruh yang diberikan oleh variabel (X1), (X2), dan (X3) secara simultan sebesar $34,3 \%$.

\subsection{Pembahasan}

\section{Kelayakan Aspek Keuangan}

Di dalam aspek keuangan, ada enam kriteria penilaian investasi yang dapat di uraikan sebagai berikut:

(1) Payback Period (PP), adalah suatu indikator untuk mengetahui seberapa lama biaya investasi usaha yang dikeluarkan akan kembali melalui keuntungan yang diperoleh atas usaha tersebut Berdasarkan hasil perhitungan payback period pada usaha RBW ukuran 4 X 12 X 3 LT di atas menunjukkan sebesar 4,11 artinya pengembalian investasi berlangsung dalam waktu 4 tahun 11 bulan sehingga usaha ini dinilai cukup baik untuk dilaksanakan karena pay back periode < dari umur proyek.

(2) Break Event Point (BEP), adalah analisa dimana keadaan usaha yang telah mencapai suatu titik tidak untung dan juga tidak rugi atau pada titik impas. Dari hasil perhitungan BEP di atas diperoleh nilai titik impas pada posisi produksi sarang walet sebanyak $30,17 \mathrm{~kg}$ atau penjualan pada nilai Rp 407.345.952,-. Artinya usaha RBW akan mendapat keuntungan apabila produksi sarang walet mencapai lebih dari 30,17 $\mathrm{kg}$ dan akumulasi penjualan diatas $\mathrm{Rp}$ 407.345.952,--

(3). Net Present Value (NPV), adalah merupakan nilai sekarang dari selisih antara biaya dan manfaat. Suatu usaha dikatakan bermanfaat dan layak untuk di laksanakan apabila nilai NPV lebih 
besar dari 0 sedangkan apabila NPV sama dengan 1 artinya mengembalikan sebesar biaya yang dikeluarkan, sehingga keputusan untuk meneruskan usaha sangat tergantung pada pengelola, akan dilaksanakan atau tidak.

Berdasarkan hasil perhitungan pada usaha RBW di atas menunjukkan NPV sebesar Rp 231.901.674 dan bernilai positif. Pada tingkat suku bunga $12 \%$ dari hasil NPV yang lebih besar dari nol tersebut maka usaha dikatakan layak untuk dilaksanakan.

(4) Profitability Index (PI), adalah metode yang menghitung perbandingan antara nilai sekarang penerimaan kas bersih masa yang akan datang dengan nilai sekarang investasi. Jika PI > dari 1 maka usaha dapat dikatakan layak dan menguntungkan, tetapi jika < dari 1 maka usaha dinyatakan tidak layak. Dari hasil perhitungan profitability index didapatkan nilai sebesar 2,2 yang berarti bernilai lebih dari 1. Dengan demikian perputaran investasi yang ditanamkan berdasarkan kas bersih yang dihasilkan selama jangka waktu yang diinginkan pada usaha rumah burung walet di kecamatan Lalan kabupaten Musi banyuasin layak untuk dijalankan dan berpotensi menguntungkan.

(5) Net Benefit/Cost Ratio (Net B/C), adalah membandingkan jumlah NPV positif dengan NPV negatif. Hasil perhitungannya dapat menggambarkan benefit yang akan diperoleh berapa kali lipat dari cost yang dikeluarkan Berdasarkan hasil perhitungan Net B/C ratio di atas pada faktor diskonto $12 \%$ adalah sebesar 4,75. Dengan kata lain dapat dijelaskan bahwa setiap pengeluaran sekarang sebesar Rp 1 akan memberikan manfaat (benefit) sebesar Rp 4.75 kali lipat dari cost yang dikeluarkan. Nilai Net $\mathrm{B} / \mathrm{C}$ ratio ini $>1$ maka usaha $\mathrm{RBW}$ menguntungkan dan layak untuk dilaksanakan.

(6) Internal Rate of Return (IRR), merupakan metode kelayakan investasi dengan menyamakan present value aliran kas dengan present value investasi. Hasil perhitungan IRR dari analisis di atas dengan tingkat discount factor (df) 26\% dan 27\% didapatkan hasil 26\%. Ini artinya nilai IRR lebih besar dari tingkat suku bunga pinjaman saat ini yaitu $12 \%$, dengan demikian usaha RBW ini layak untuk dijalankan.

Dari analisis-analisis keenam kriteria investasi di atas dapat disimpulkan bahwa ditinjau dari kelayakan aspek keuangan usaha rumah burung walet di kecamatan Lalan ini layak untuk dijalankan, hal ini sejalan dengan hasil penelitian Saipullah (2018).

\section{Kelayakan Aspek Pemasaran}

Ditinjau dari segi aspek pemasaran, usaha peternakan walet di kecamatan Lalan ini layak untuk dilaksanakan, hal ini dapat dilihat dari skor rata-rata hasil wawancara dalam kuisioner dengan responden sebesar 3,88 atau 77,71 termasuk kategori layak, hal ini sejalan dengan hasil penelitian Saipullah, (2018) dan hasil penelitian Sudarna dan Suparta (2013). Pemasaran hasil walet di kecamatan Lalan telah berjalan dengan baik dengan harga yang relatif tinggi, walaupun penjualan walet masih dilakukan kepada orang perorangan karena belum adanya wadah organisasi atau badan usaha seperti Koperasi Unit Desa (KUD).

\section{Kelayakan Aspek Teknik}

Jika ditinjau dari usaha aspek teknk usaha peternakan walet ini juga layak, hal ini dibuktikan dari skor rata-rata hasil wawancara dalam kuisioner dengan responden sebesar 3,73 atau 74,67 termasuk kategori layak, ini juga sejalan sengan hasil penelitian Saipullah, (2018).

Teknologi yang menunjang usaha walet ini merupakan teknologi secara umum dan sederhana, seperti ketersediaan air bersih, tenaga surya, ketersediaan tweter yang memadai, pengatur suhu dan kelembaban udara ruangan serta CTTV, hal ini juga harus didukung oleh ketersediaan listrik yang memadai, mengingat kecamatan Lalan merupakan daerah perairan pasang surut yang baru teraliri listrik 24 jam sehari pada awal tahun 2020. Dengan demikian, rumah burung walet (RBW) yang dibangun sangat mendekati lingkungan habitat burung walet 
yang sesungguhnya seperti di goa-goa yang jauh dari polusi. Kemudian cara kebiasaan para peternak walet memproduksi sarang walet dengan membuang telurtelur walet dari sarangnya secara berlebihan akan merusak keseimbangan habitat walet di masa yang akan datang.

\section{Pengaruh Aspek Keuangan Terhadap Pendapatan Peternak Walet}

Aspek keuangan terbukti tidak berpengaruh terhadap pendapatan peternak walet di kecamatan Lalan kabupaten Musi Banyuasin. Berdasarkan uji-t bahwa variabel aspek keuangan pada hasil pengujian tingkat signifikan sebesar $0.136>$ dari 0.05 pada tingkat kepercayaan 95\%, artinya tidak ada pengaruh signifikan antara variabel aspek keuangan terhadap pendapatan.

\section{Pengaruh Aspek Pemasaran Terhadap Pendapatan Peternak Walet}

Aspek pemasaran terbukti berpengaruh terhadap pendapatan peternak walet di kecamatan Lalan kabupaten Musi Banyuasin. Berdasarkan uji-t bahwa variabel aspek pemasaran pada hasil pengujian tingkat signifikan sebesar $0.000<$ dari 0.05 pada tingkat kepercayaan 95\%, artinya ada pengaruh signifikan antara variabel aspek pemasaran terhadap pendapatan.

\section{Pengaruh Aspek Teknik Terhadap Pendapatan Peternak Walet}

Aspek teknik terbukti berpengaruh terhadap pendapatan peternak walet di kecamatan Lalan kabupaten Musi Banyuasin. Berdasarkan uji-t bahwa variabel aspek teknik pada hasil pengujian tingkat signifikan sebesar $0.01<$ dari 0.05 pada tingkat kepercayaan $95 \%$, artinya ada pengaruh signifikan antara variabel aspek teknik terhadap pendapatan.

\section{Pengaruh Aspek Keuangan, Aspek Pemasaran, dan Aspek Teknik Terhadap Pendapatan Peternak Walet}

Aspek keuangan, aspek pemasaran, dan aspek teknik secara simultan terbukti berpengaruh terhadap pendapatan peternak walet di kecamatan Lalan kabupaten Musi Banyuasin. Berdasarkan ujiF menunjukkan variabel aspek keuangan (X1), variabel aspek pemasaran (X2), dan variabel aspek teknik (X3) dapat menjelaskan variabel pendapatan (Y) sebesar 34,3\%. Untuk pengujian secara simultan dapat dilihat nilai signifikansi $\mathrm{F}$ hitung sebesar 0.000 $<0.05$ adalah terbukti bahwa terdapat pengaruh signifikan variabel aspek keuangan, variabel aspek pemasaran, dan variabel aspek teknik terhadap variabel pendapatan, hal ini sejalan dengan hasil penelitian Saipullah, (2018).

\section{Aspek Kelayakan Bisnis yang Paling Dominan Terhadap Pendapatan Peternak Walet}

Untuk mengetahui aspek kelayakan usaha yang paling domiinan terhadap pendapatan peternak dapat dilihat pada nilai Beta (f) dalam hasil analisis regresi linear berganda dalam tabel 7 . Adapun nilai $f$ yang paling tinggi adalah variabel aspek pemasaran (X2) sebesar $f=0.490$, kemudian berikunya diikuti oleh variabel aspek teknik (X3) sebesar $f=0.178$, serta nilai $\mathrm{f}$ yang terkecil yaitu variabel aspek keuangan sebesar - 0.073 . Dengan demikian kontribusi terbesar dalam peningkatan pendapatan peternak walet adalah dari aspek pemasaran.

\section{Kebutuhan Dana Investasi Usaha Peternakan Walet}

Kebutuhan dana investasi awal usaha peternakan walet di Kecamatan Lalan untuk ukuran rumah burung walet (RBW) $4 \times 12$ × 3 Lantai yang dibangun pada tahun 2019 adalah sebesar Rp 186.439.100,- (tabel 2.). Sedangkan biaya operasional selama 15 tahun ke depannya adalah sebesar Rp 670.373.956,- (tabel 3.).

\section{KESIMPULAN DAN SARAN}

\subsection{Kesimpulan}

Kesimpulan yang dapat ditarik berdasarkan 


\section{Forum Bisnis Dan Kewirausahaan Jurnal Ilmiah STIE MDP}

analisa dan pembahasan dalam penelitian ini adalah sebagai berikut:

1. Usaha peternakan walet di kecamatan Lalan kabupaten Musi Banyuasin layak untuk diusahakan ditinjau dari kelayakan aspek keuangan, pemasaran dan teknik.

2. Aspek pemasaran dan aspek teknik secara parsial berpengaruh signifikan terhadap pendapatan peternak walet.

3. Aspek keuangan, aspek pemasaran dan aspek teknik secara simultan berpengaruh signifikan terhadap pendapatan peternak walet.

4. Aspek kelayakan bisnis yang memiliki pengaruh paling dominan terhadap pendapatan peternak walet adalah aspek pemasaran jika dibandingkan dengan aspek keuangan dan teknik.

5. Kebutuhan dana investasi usaha peternakan walet untuk ukuran rumah burung walet (RBW) 4 x 12 $\mathrm{x} 3$ lantai, terdiri dari modal investasi awal sebesar Rp 186.349.100,- dan modal operasional selama 15 tahun sebesar Rp 670.373.956,-.

\subsection{Saran}

Adapun saran-saran yang dapat penulis berikan dalam penelitian ini adalah sebagai berikut:

1. Diharapkan para peternak burung walet di kecamatan Lalan dapat membentuk wadah dalam suatu usaha Koperasi Unit Desa (KUD), sehingga penjualan hasil produksi sarang walet tidak dijual kepada tengkulak, akan tetapi dapat dijual kepada KUD tersebut.

2. Para peternak walet diharapkan untuk tidak membuang telur-telur walet di RBWnya secara berlebihan, agar keseimbangan habitat burung walet di masa yang akan datang dapat terjaga.

3. Diharapkan agar pemerintah setempat melakukan pendataan para peternak walet secara statistik dan melalui dinas-dinas terkait dapat melakukan pembinaan guna meningkatkan produksi sarang burung walet sebagai komoditas ekspor unggulan, juga berdampak pada meningkatnya pendapatan asli daerah (PAD) dari sektor pajak sarang burung walet.

\section{DAFTAR PUSTAKA}

[1] Anwar, Saifuddin. 2001, Metode Penelitian Pendidikan, Pustaka Pelajar, Bandung.

[2] Abdullah.HM. Ma'ruf. 2017, Studi Kelayakan Bisnis, Cetakan 1, Aswaja Pressindo, Yogyakarta.

[3] Arikunto, 2013, Prosedur Penelitian: Suatu Pendekatan Praktik, Rineka Cipta, Jakarta.

[4] Kasmir dan Jakfar. 2012, Studi Kelayakan Bisnis. Cetakan Kedelapan, Kencana, Jakarta

[5] Kasmir dan Jakfar. 2014, Studi Kelayakan Bisnis. Edisi Revisi, Prenadamedia Group, Jakarta.

[6] Margono, S. 2009, Metodologi Penelitian Pendidikan Komponen MKDK, PT Rineka Cipta, Jakarta.

[7] Muchtar A.F. 2014, Business Plan dan Rencana Aksi, Yrama Widya, Bandung.

[8] Natawirawan, 2002, Cara Mudah Memahami Statistik 2 (Statistik Inferensia) Untuk Ekonomi dan Bisnis, Ed. Kedua, Kerara Emas, Denpasar.

[9] Purwana. D., Hidayat. N. 2017, Studi Kelayakan Bisnis, Cetakan ke 2, PT Rajagrafindo Persada, Depok.

[10] Saipullah. 2018, Analisis Kelayakan Usaha Budidaya Sarang Burung Walet di Kecamatan Penyinggahan Kabupaten Kutai Barat (Studi Kasus Usaha Sarang Burung Walet Bapak Jurni): e-Journal Administrasi Bisnis, 2018, ISSN 2355-5408.

[11] Saparudin. 2012, Pertumbuhan Ekonomi, (Accesed 22 Juli 2019), http://edunomic.net/ index.php/articles/1-pertumbuhan ekonomi

[12] Sudana, Iw. Arga. N. Suparta, N. 2013, 
Kelayakan Usaha Budidaya Ikan Lele Dumbo (Clarias Gariepinus) dan Pengaruhnya Terhadap Tingkat Pendapatan Petani Ikan Lele di Kabupaten Tabana, Jurnal Manajemen Agribisnis Vol. 1, No.1, Mei 2013 Issn 2355-0759

[13] Sugiyono. 2002, Metode Penelitian Administrasi, Alfabeta, Bandung.

[14] Sugiyono. 2008, Metode Penelitian Bisnis, CV Alfabeta, Bandung.

[15] Sugiyono. 2017, Metode Peneliitian Kuantitatif, Kualitatif, dan $R \& D$, Alfabeta Bandung.

[16] Sunyoto, Danang. 2014, Studi Kelayakan Bisnis, CAPS (Center of Academic Publishing Service), Jakarta.

[17] Whalley \& Wong's. 1999, Nursing Care of Infant and Children, $6^{\text {th }}$ Edition, Mosby Company, Philadelphia 